\title{
Identification of Zeoliarus oppositus (Hemiptera: Cixiidae) as a Vector of 'Candidatus Phytoplasma australiense'
}

C. J. Winks, Landcare Research, Private Bag 92170, Auckland 1142, New Zealand; M. T. Andersen and J. G. Charles, The New Zealand Institute for Plant \& Food Research Ltd., Private Bag 92169, Victoria Street West, Auckland 1142, New Zealand; and R. E. Beever, Landcare Research, Auckland, New Zealand

\begin{abstract}
Winks, C. J., Andersen, M. T., Charles, J. G., and Beever, R. E. 2014. Identification of Zeoliarus oppositus (Hemiptera: Cixiidae) as a vector of 'Candidatus Phytoplasma australiense'. Plant Dis. 98:10-15.

'Candidatus Phytoplasma australiense' is associated with a number of plant diseases in New Zealand. The only known vector of this pathogen was Zeoliarus atkinsoni, a planthopper considered to be monophagous on New Zealand flax (Phormium spp.). The work carried out shows that $Z$. oppositus, which is polyphagous, is able to vector ' $C a$. P. australiense' to both Coprosma robusta (karamu) and Cordyline australis (New Zealand cabbage tree). Although transmission was achieved to both these species, the disease symptomatology was more evident in $C$. australis. Two approaches were taken to achieve transmission. First, insects were collected from areas around symptomatic Coprosma

plants and caged directly on test plants. Second, insects were collected from grasses and sedges in areas where disease was less evident and were fed on known infected Coprosma plants prior to being caged on test plants. Transmission was achieved using both approaches, although transmission was far greater (30\% compared with $4 \%$ ) from insects that were directly applied. Phytoplasma DNA was detected in $12 \%$ of $Z$. oppositus individuals tested during all the trials. This work identifies a new vector for ' $\mathrm{Ca}$. P. australiense' and contributes to our understanding of the ecology of Cordyline sudden decline and Coprosma lethal decline.
\end{abstract}

Phytoplasmas are specialized plant-pathogenic bacteria (class Mollicutes) that are believed to be responsible for diseases in hundreds of plant species, many of which are economically important (22). They occupy the phloem cells of their host plants and the tissues of phloem-feeding insects that transmit them (16,22). Phytoplasmas can also be transmitted by grafting but, despite some reports, there is no conclusive evidence supporting seed transmission (22). Despite increasing knowledge of these organisms, particularly with the development of molecular techniques and subsequent genome sequencing, the axenic culturing of phytoplasmas is still problematic. They cannot be formally named under the present International Code of Nomenclature of Bacteria but are informally designated as species of the 'Candidatus Phytoplasma' genus based on 16S ribosomal RNA (rRNA) gene sequences (17). Methods for control almost exclusively focus on limiting their spread by identification and elimination of infected plant material and by controlling the insect vectors.

A number of species of the order Hemiptera, primarily leafhoppers, planthoppers, and psyllids, are known to vector phytoplasmas (33). The transmission ecology for phytoplasmas is a complex process requiring the bacterium to cross a number of barriers within the vector, from the gut to the salivary gland. Even then, they must accumulate to high numbers in the posterior acinar cells of the salivary gland before they can be transmitted (18,33). Consequently, insects may acquire phytoplasma through normal feeding behavior but may not become infectious because the bacterium does not move into the appropriate tissues, or not in sufficient quantity. With the advances in understanding the genetic complement of phytoplasmas through the sequencing of complete genomes, the underlying molecular mechanisms responsible for vector specificity are starting to be determined $(7,14,32)$.

Corresponding author: M. T. Andersen,

E-mail: mark.andersen@plantandfood.co.nz

Accepted for publication 8 July 2013.

http://dx.doi.org/10.1094/PDIS-04-13-0421-RE

(c) 2014 The American Phytopathological Society
'Candidatus Phytoplasma australiense' (12) is associated in New Zealand with diseases of five host species: two monocotyledons, New Zealand flax (Phormium tenax) and New Zealand cabbage tree (Cordyline australis); and three dicotyledons, strawberry (Fragaria $\times$ ananassa), and two species of Coprosma (Coprosma robusta and $C$. macrocarpa). Phormium yellow leaf was first reported in 1908, whereas the other four diseases have only been described since the late 1970 s $(2,3,5,6,26)$. Since 2008, ' $C a$. P. australiense' has been reported in potato (Solanum tuberosum), Jerusalem cherry (S. pseudocapsicum), swan plant (Gomphocarpus fruticosa), and celery (Apium graveolens) and in connection with a new disease of Boysenberry (Rubus hybrid) in New Zealand $(27,28,34)$.

Previous work $(10,25)$ established that ' $\mathrm{Ca}$. P. australiense' is transmitted from Phormium to Phormium by the New Zealand flax planthopper Oliarus atkinsoni (Cixiidae). Species of Oliarus that are endemic to New Zealand have recently been placed in a new genus, Zeoliarus (20). Zeoliarus atkinsoni is largely restricted to Phormium spp. and, therefore, it was considered that at least one other, polyphagous vector must exist to explain the spread of ' $\mathrm{Ca}$. P. australiense' from Phormium spp. to other plant hosts of the more recently emerged diseases $(2,6)$. Initial research focused on exotic insects that had arrived about the time the new diseases started to be reported. Phytoplasma DNA was detected in two exotic planthoppers-Scolypopa australis (Ricaniidae) and Siphanta acuta (Flatidae) - but all attempts to show transmission by those insects failed $(5,6,25)$. ' $C a$. P. australiense' DNA was also detected in Arawa variegata and Recilia hospes, two leafhoppers (Cicadellidae) that were commonly found in the vicinity of infected strawberry plants (9). Preliminary polymerase chain reaction (PCR) analysis of members of Hemiptera feeding in the vicinity of symptomatic plants indicated the presence of phytoplasma DNA after only one-stage PCR in Z. oppositus, the only other species of the Zeoliarus genus in New Zealand (19). Consequently it was decided to test transmission of ' $\mathrm{Ca}$. $\mathrm{P}$. australiense' using the native insect $Z$. oppositus.

\section{Materials and Methods}

Plants. Test plants of Cordyline australis and Coprosma robusta were sourced from a nursery at least $200 \mathrm{~km}$ from any reported 
phytoplasma disease and grown from seed under insect-proof conditions. Plants were grown in potting mix in a temperature-controlled greenhouse at a temperature of approximately 20 to $25^{\circ} \mathrm{C}$ and with ambient light hours. Seedlings used in the experiments were at least $20 \mathrm{~cm}$ in height.

Insects. Z. oppositus (Fig. 1) adults were collected in spring and summer (November to February 2004-05 and 2005-06) from grasses and sedges and also symptomatic and nonsymptomatic shrubs of $C$. robusta at four sites in and around the Bay of Plenty (BoP) region and two sites in metropolitan Auckland. All collection sites were no more than $50 \mathrm{~m}$ from symptomatic Coprosma plants. Insects were collected using a combination of sweep nets, beating trays, and mouth aspirators. BoP site 1 (S1) was a restoration site where Coprosma lethal decline (CLD) had been detected (6) and which was upwind of strawberry beds where strawberry lethal yellows (SLY) had also been regularly reported (3). BoP sites 2, 3, and 4 were associated with stands of native flora, including $C$. robusta displaying reddening and bronzing symptoms indicative of possible phytoplasma infection. The two Auckland sites were in the metropolitan area and contained stands of $C$. robusta showing symptoms of bronzing and dieback. ' $\mathrm{Ca}$. P. australiense' had been detected in C. robusta at Auckland site 2, which was the source of grafted material described previously (6). In total, 140field collected Z. oppositus individuals were tested for the presence of ' $\mathrm{Ca}$. P. australiense', and 745 insects were used in the caged trials (Table 1).

Transmission. In total, 12 transmission experiments were set up spanning two seasons. Experiments T1, T2, and T8 to T12 were set up in 2004-05, and T3 to T7 were set up in 2005-06. Two types of experiments were performed. In the first (T1 to T7), insects collected from the field were caged with test plants and, in the second (T8 to T12), field-collected insects were caged with C. macrocarpa plants that had previously been tested positive for ' $\mathrm{Ca}$. P. australiense' (6), then caged with test plants.

Experiments T1 to T7 involved caging 10 to 20 individuals of $Z$. oppositus with seedlings of the test species Cordyline australis or Coprosma robusta (3 to 10 replicates) (Table 1A). Insects were collected from BoP S1 for T1 to T5, and BoP S2 and S3 for trials T6 and T7 respectively. Insects were left on test plants for 14 to 34 days and then removed.

Experiments T8 to T12 (Table 1B) involved caging 5 to $10 \mathrm{Z}$. oppositus collected from sedges and grasses around Auckland and BoP regions onto ' $C a$. P. australiense'-positive $C$. macrocarpa plants for 15 to 29 days and then caging the insects with Cordyline australis (two to six replicates). The insects were not removed from the test plants but remained there until they died.
The transmission experiments were carried out with the same conditions as for growing the plants. Cages were made of fine curtain mesh (voile) and were a simple bag design, sewn along one side and the bottom and tied at the top, and were large enough to enclose entire plants. Cages without insects were placed on control plants. Methods used were based on previous experiments (25), and a review of techniques can be found in Bosco and Tedeschi (7). Test plants and controls were examined regularly for symptoms for up to 1 year.

DNA extraction. Plant tissue of $C$. australis for DNA analysis was sampled from the shoot, leaf base, rhizome apex, and roots following destructive harvesting, whereas only leaf and petioles of Coprosma robusta were sampled. The Cordyline australis seedlings were harvested once they presented with symptoms of CSD (Fig. 2), whereas Coprosma robusta tissue was sampled after 1 year. Samples were ground from fresh tissue in liquid nitrogen and held at $-80^{\circ} \mathrm{C}$ prior to nucleic acid extraction. DNA was extracted using a modified cetyltrimethylammonium bromide method (2), and DNA quality and PCR competency for plant samples was checked using universal prokaryotic primers Gd1 and Berg54 (1).

Upon removal from plants, insects were preserved in $70 \%$ ethanol. Unless otherwise stated, DNA was extracted from individual whole insects following the method of Newcomb and Gleeson (29).

PCR. Insects and plant samples were tested for the presence of phytoplasma DNA using one-stage and nested-PCR with the universal phytoplasma $16 \mathrm{~S}$ primers P1 and P7 $(13,31)$ or R16F2n and R16R2 $(15,23)$. Primers for PCR of the tuf gene were fTufAY and rTufAY (30) and Tuf1FA and Tuf4R (4).

PCR conditions. DNA (10 to $50 \mathrm{ng}$ ) from plant or insects was amplified in either a Corbett FTS-1S or FTS-4000 Thermal Sequencer with the following conditions for all PCR reactions: $94^{\circ} \mathrm{C}$ for $2 \mathrm{~min}, 53^{\circ} \mathrm{C}$ for $1 \mathrm{~min}$, and $72^{\circ} \mathrm{C}$ for $2 \mathrm{~min}$ for 1 cycle; then, $94^{\circ} \mathrm{C}$ for $1 \mathrm{~min}, 53^{\circ} \mathrm{C}$ for $30 \mathrm{~s}$, and $72^{\circ} \mathrm{C}$ for $2 \mathrm{~min}$ for 35 cycles. Reactions contained $20 \mathrm{mM}$ Tris- $\mathrm{Cl}(\mathrm{pH} 8.4), 50 \mathrm{mM}$ $\mathrm{KCl}, 200 \mu \mathrm{M}$ dNTPs, $1.5 \mathrm{mM} \mathrm{MgCl}_{2}$, and $0.5 \mathrm{U}$ of $\mathrm{Taq}$ polymerase (Invitrogen), with a final concentration of $100 \mathrm{nM}$ for each primer.

Sequencing. DNA sequencing was conducted on PCR products using an ABI Prism 377 (PE Applied Biosystems) with Big Dye Terminator chemistry. PCR products were sequenced, with primers and salts removed by passing samples through an S300HR size-exclusion column (GE Healthcare Life Sciences). Primers used for sequencing were P1, P7, R16F2n, and R16R2 for the 16S rRNA gene, or fTufAY, rTufAY, Tuf1FA, or Tuf4R for the $t u f$ gene.

Table 1. Transmission experiments involving Zeoliarus oppositus onto either Coprosma robusta or Cordyline australis ${ }^{\mathrm{a}}$

\begin{tabular}{|c|c|c|c|c|c|c|c|}
\hline Test, trial & Start date & Test plant & $\begin{array}{c}\text { First source of } \\
\text { Z. oppositus }\end{array}$ & Insects & $\begin{array}{l}\text { Feeding time on } \\
\text { test plant (days) }\end{array}$ & $\begin{array}{c}\text { Plant } \\
\text { positives/total }\end{array}$ & $\begin{array}{c}\text { Plant } \\
\text { controls }\end{array}$ \\
\hline \multicolumn{8}{|l|}{ A } \\
\hline \multirow{2}{*}{$\mathrm{T} 1$} & 3 December 2004 & Coprosma robusta & BoP S1 & 100 & 23 & $2 / 10$ & 2 \\
\hline & Total & $\ldots$ & & 100 & $\ldots$ & $2 / 10$ & $\ldots$ \\
\hline $\mathrm{T} 2$ & 10 December 2004 & Cordyline australis & BoP S1 & 100 & 25 & $4 / 10$ & 2 \\
\hline $\mathrm{T} 3$ & 13 December 2005 & C. australis & BoP S1 & 160 & 34 & $3 / 8$ & 2 \\
\hline $\mathrm{T} 4$ & 28 December 2005 & C. australis & BoP S1 & 100 & 15 & $3 / 10$ & 5 \\
\hline $\mathrm{T} 5$ & 19 January 2006 & C. australis & BoP S1 & 60 & 14 & $1 / 3$ & $7^{b}$ \\
\hline T6 & 19 January 2006 & C. australis & BoP S2 & 60 & 14 & $0 / 3$ & $\ldots$ \\
\hline \multirow[t]{2}{*}{$\mathrm{T} 7$} & 19 January 2006 & C. australis & BoP S3 & 60 & 14 & $0 / 3$ & $\ldots$ \\
\hline & Total & $\ldots$ & $\ldots$ & 540 & $\ldots$ & $11 / 37$ & $\ldots$ \\
\hline \multicolumn{8}{|l|}{ B } \\
\hline $\mathrm{T} 8$ & 7 January 2005 & C. australis & Auckland S1 & 25 & 21 & $1 / 5$ & 2 \\
\hline T9 & 10 January 2005 & C. australis & BoP S3 & 50 & 21 & $0 / 5$ & 2 \\
\hline $\mathrm{T} 10$ & 17 January 2005 & C. australis & Auckland S2 & 50 & 15 & $0 / 5$ & 2 \\
\hline $\mathrm{T} 11$ & 2 February 2005 & C. australis & BoP S4 & 60 & 20 & $0 / 6$ & 2 \\
\hline \multirow[t]{2}{*}{$\mathrm{T} 12$} & 11 February 2005 & C. australis & BoP S3 & 20 & 29 & $0 / 2$ & 2 \\
\hline & Total & $\ldots$ & $\ldots$ & 205 & $\ldots$ & $1 / 23$ & $\ldots$ \\
\hline
\end{tabular}

${ }^{a}$ Insects were either caged onto target plants directly from the field (A) or were fed on Coprosma macrocarpa plants that had previously been tested positive for 'Candidatus Phytoplasma australiense' and then caged on to test plants (B). BoP = Bay of Plenty sites (S) 1 through 4.

b Seven plants for entire 19 January 2006 experiment. 


\section{Results}

Insects. In total, 17 (from 140) Z. oppositus adults collected from the field over three seasons (2003 to 2005) tested positive for phytoplasma DNA using primers P1/P7 or fTuf AY and rTufAY (single-stage PCR), a rate of approximately $12 \%$. The $16 \mathrm{~S}$ rRNA gene of two of these PCR products were sequenced, confirming that the phytoplasma present was ' $\mathrm{Ca}$. P. australiense'. The PCR products matched $100 \%$ with PYL $16 \mathrm{~S} r r n A$ and PYL $16 \mathrm{~S} r r n B$ (GenBank accession numbers U43569 and U43570, respectively), including ambiguities where the two operons differ in sequence (24; data not shown). The tuf gene PCR product of four samples were sequenced and two matched $100 \%$ with variant group VII (GenBank accession DQ094778), one with variant group VIII (GenBank accession DQ094779), and the other with variant group IX (GenBank accession DQ094780) (4; data not shown). This meant that representatives of ' $\mathrm{Ca}$. $\mathrm{P}$ australiense' clades tuf 1 and tuf 2 were both detected in Z. oppositus.

Over $60 \%$ of the $Z$. oppositus adults that were caged directly from the field onto Cordyline australis or Coprosma robusta test plants were still alive on removal after periods of 14 to 34 days. A selection of these live insects was tested and phytoplasma DNA was detected in 6 of $36(17 \%)$ of them. This compared with 4 of 29 $(14 \%)$ insects that were tested after being fed on potted phytoplasma-positive C. macrocarpa plants for periods of 15 to 29 days (Table 2).

Transmission. Symptoms of reddening and dieback were widespread throughout the C. robusta plants. All 12 plants in trial 1 (T1) were tested using one-stage and nested-PCR. Phytoplasma DNA was detected in 2 of the 10 test samples but not in either of the two control plants (Table 1A).

For Cordyline australis, 20\% (12/60) of seedlings (T2 to T12) exposed to $Z$. oppositus showed sudden decline symptoms (Fig. 3A) within 1 year, with the first symptoms observed after 63 days and the last after 164 days. Sudden decline symptoms in the shoot closely resembled those of initially affected tufts of diseased trees observed in the field (Fig. 3B) (2,5). Symptomatic plants were harvested at 63 to 164 days (Fig. 2), along with companion nonsymptomatic control plants. No control plants showed any sign of phytoplasma infection.

Tissue samples from 13 symptomatic plants were examined for the presence of phytoplasma DNA. PCR-competent DNA extracts were obtained from shoot, rhizome, and leaf base samples but seldom from root samples. At least one of the tissue samples from each of 12 symptomatic plants was positive for phytoplasma $16 \mathrm{~S}$ rDNA using one-step PCR, whereas all tissue samples from 9 of the nonsymptomatic control plants were negative after nested-PCR. The 16S rRNA PCR products from plants T8_Ca1, T2_Ca2, and T2_Ca7 were sequenced, confirming that the phytoplasma detected was ' $\mathrm{Ca}$. P. australiense'. One plant from trial T4 (T4_Ca1) died displaying symptoms similar to Cordyline sudden decline (CSD) but phytoplasma DNA could not be detected when tested by nestedPCR. The death of this plant was not considered to be due to CSD.

\section{Discussion}

This article describes the results of 12 phytoplasma transmission experiments performed over two consecutive years. As previously reported, it can be difficult to correlate symptoms in Coprosma spp. with the presence of phytoplasma (6). The data of the single Coprosma experiment presented here consist of each plant being tested by nested-PCR. In contrast, phytoplasma-specific symptoms in $C$. australis are more obvious and, consequently, these plants were preferentially monitored in the transmission studies. Generally, testing by PCR was performed on those samples of Cordyline

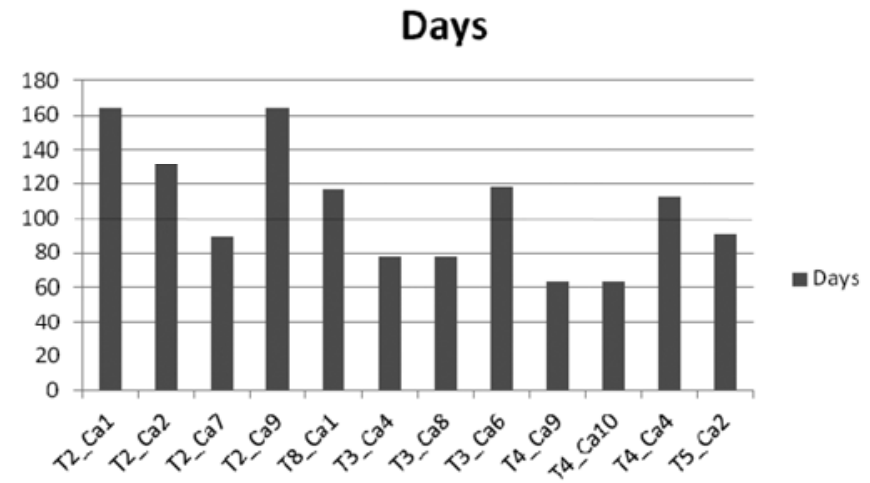

Fig. 2. Cordyline australis samples that tested positive for the presence of phytoplasma after transmission experiments with Zeoliarus oppositus. Sample name is plotted against the number of days before the presentation of symptoms was significant to warrant destructive testing. The first part of the sample name refers to the appropriate trial as listed in Table 1.

\section{Photographer: B.E. Rhode, Landcare Research}

Fig. 1. Zeoliarus oppositus adult. Solid bar represents $1 \mathrm{~mm}$. 
Table 2. Samples of Zeoliarus oppositus that tested positive for the presence of phytoplasma by polymerase chain reaction ${ }^{\mathrm{a}}$

\begin{tabular}{|c|c|c|c|}
\hline \multirow[b]{3}{*}{ Insects } & \multicolumn{3}{|c|}{ Samples } \\
\hline & \multirow{2}{*}{$\begin{array}{c}\text { 2003-2006 } \\
\text { Tested }\end{array}$} & \multicolumn{2}{|c|}{$2004-2006^{b}$} \\
\hline & & Field & Caged \\
\hline Positive & 17 & 6 & 4 \\
\hline Total tested & 140 & 36 & 29 \\
\hline Detection rate $(\%)$ & 12 & 17 & 14 \\
\hline
\end{tabular}

a The first column summarizes all insects tested over 4 years. The other two columns summarize samples collected in association with the transmission trials in the years 2004 to 2006.

b Samples collected from field (Field) and samples after being caged on infected Coprosma plants (Caged). spp. showing CSD-like symptoms, although nine other nonsymptomatic plants were tested as controls. Of symptomatic plants of $C$. australis, all but one tested positive for phytoplasma DNA, and none of the nonsymptomatic $C$. australis controls produced an amplicon after nested-PCR with phytoplasma-specific primers. It was not clear why the one sample that appeared symptomatic did not test positive for phytoplasma. It is possible that this plant succumbed to another pathogen but we did not investigate further, and the plant was not considered an example of successful phytoplasma transmission. The evidence presented here indicates that Z. oppositus is a vector of ' $C a$. P. australiense', capable of transmitting this phytoplasma to both $C$. australis and Coprosma robusta.

The ecology of Z. oppositus is consistent with the proposition that it is a vector for ' $\mathrm{Ca}$. P. australiense'. It is a very common
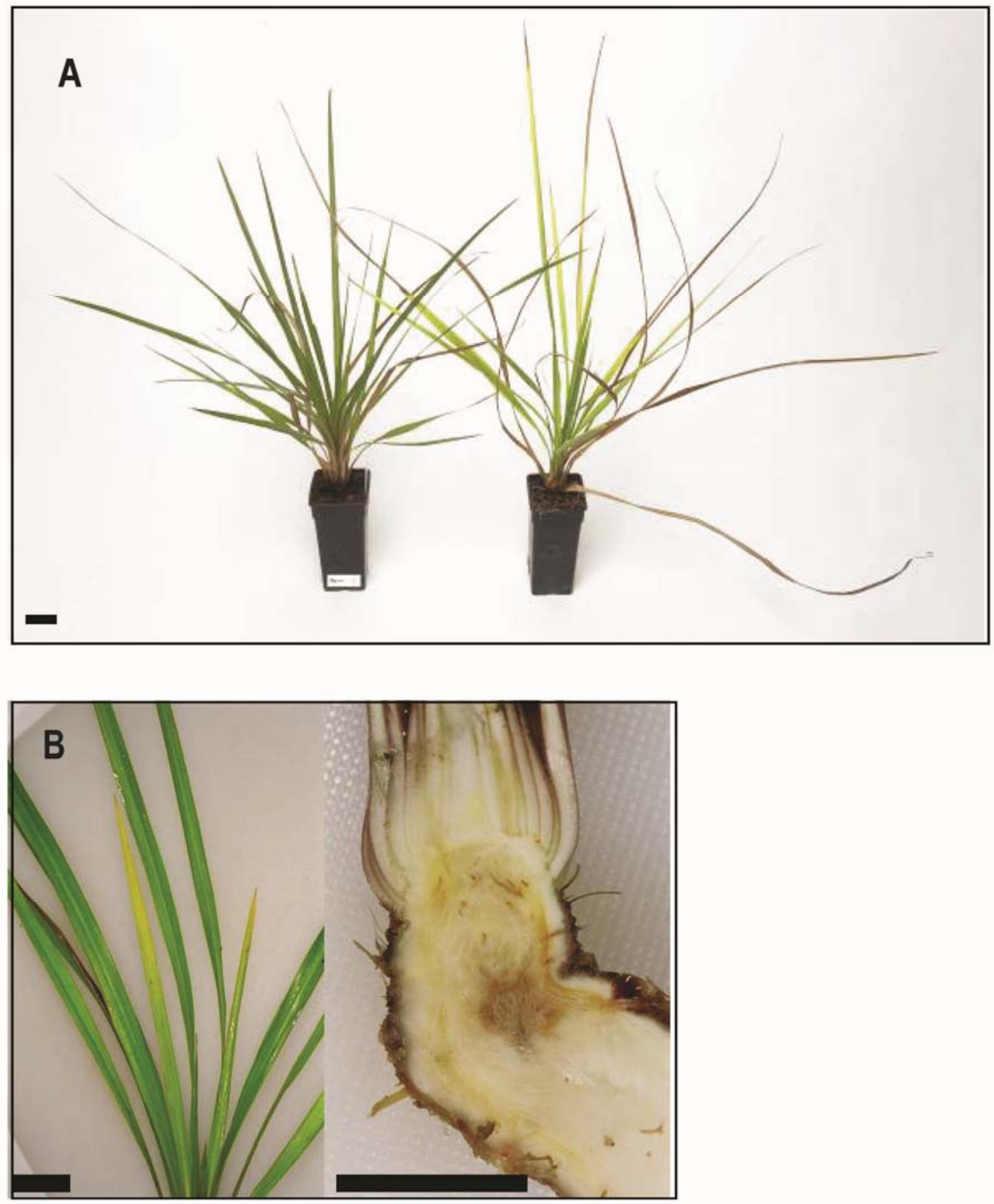

Fig. 3. Cordyline disease symptoms associated with Zeoliarus oppositus exposure. A, Control plant (left) and symptomatic plant T2_Ca2 (right) showing leaf yellowing and browning from the tip. B, Plant T2_Ca9 showing leaf yellowing (left), and shoot apex in section (right) showing block of brown necrosis and reddish-brown discoloration of the vascular strands. Solid bar represents $2 \mathrm{~cm}$ 
species in natural and modified habitats throughout New Zealand in lowland to subalpine habitats $(11,19)$, and its distribution encompasses the known range of ' $\mathrm{Ca}$. P. australiense'. Unlike $Z$. atkinsoni, it is polyphagous and has been reported from many plant species-especially those associated with low herbage, including sedges and grasses as well as Phormium spp. (11). The nymphal stage of Z. oppositus probably feeds underground on plant rhizomes and roots, with adults present mostly over the summer months, although the detailed life cycle of most known species of Cixiidae has not been verified (21). It remains to be determined at what stage the insects need to acquire the phytoplasma to be infectious. The fact that more than $60 \%$ survived after 3 weeks on Cordyline australis and Coprosma spp., together with direct observations of their behavior in the cages, indicates that $Z$. oppositus must feed on these hosts, consistent with it being a vector to these plants. In view of its known occurrence on Phormium spp., it may also vector the phytoplasma to this host. In contrast, $Z$. oppositus survived poorly on strawberry, with none of a sample of 50 surviving at 3 weeks (data not shown). however, this does not exclude the possibility that transmission occurs, and it may be a vector for strawberry lethal yellows. The planthopper Hyalesthes obseletus has been shown to vector stolbur phytoplasma to grapevine even though it has a "scarce propensity" to feed on that host (8). Additionally, given the polyphagous nature of $Z$. oppositus, it is apparent that it may transmit the phytoplasma to other plants, including new plant hosts recently reported by Liefting et al. $(27,28)$.

The experiments where insects were field collected from symptomatic Coprosma robusta plants and were applied directly onto the test plants showed more positive transmissions (11 of 37) than those experiments where insects were caged onto infected potted Coprosma plants prior to being applied to the test plants (1 of 23). This was despite the fact that phytoplasma was detected in a similar percentage of insects from both experiments: $17 \%$ (direct from field) versus $14 \%$ (from infected potted Coprosmas plants). This could be an artifact of sampling or it could reflect the complexity of what is required for an insect to become infective. The insects that were caged onto infected potted Coprosma plants may have acquired phytoplasma from the plants but may not have had enough time to become infective, because most of these insects were collected from grasses and sedges and few may have been infected when collected. It has been reported that, for phytoplasmas, the latent period, which is the time between acquisition and when the insect is capable of transmitting the phytoplasma, can vary from a few to 80 days (33). Another possible explanation is that the extra time spent on infected Coprosma plants altered the feeding behavior of the insects, and fewer potentially transmissible feeds were made.

DNA from whole insects was used for the PCR assay and, therefore, the presence of phytoplasma DNA could indicate that the insect had fed on an infected plant and had phytoplasma in its gut; however, it should not be interpreted that the insect was infective or will be in the future. For our studies, we used a onestage PCR (with primers P1/P7). We avoided using nested-PCR for insects because we thought that, due to the far greater sensitivity, it would be more likely to detect phytoplasma that had just recently been acquired through feeding. For this reason, undue weight should not be placed on the data concerning detection rates in insects.

This is the first report of a phytoplasma being transmitted experimentally to Cordyline australis. This result supports the claim that ' $\mathrm{Ca}$. P. australiense' is responsible for the disease CSD. Phytoplasmas are presently unable to be universally cultured axenically and, therefore, true Koch's postulates cannot be performed. The previous assessment was based on correlation of the presence of phytoplasma with disease symptoms, together with symptom remission when treated with the phytoplasma-sensitive antibiotic, tetracycline. Previous attempts to achieve transmission by grafting and dodder have been unsuccessful, as were attempts using the only vector known at the time, Z. atkinsoni $(5,25)$.
The identification of Z. oppositus as a phytoplasma vector means that two vectors are now known in New Zealand. We believe that these two vectors could account for disease observations made to date, with occasional transmission of ' $\mathrm{Ca}$. P. australiense' from Phormium plants into C. robusta by either vector, and then greater spread to other plants by Z. oppositus. The dramatic and highly visible outbreak noticed in the 1980s could be the result of widespread plantings of $C$. robusta in the 1970s. This does not, however, exclude other possibilities, such as strain variation in ' $C a$. P. australiense' or the existence of other key plant hosts or vectors.

\section{Acknowledgments}

This work was funded by New Zealand's Foundation for Research, Science and Technology and the Ministry of Research, Science and Technology. We thank L. Liefting for useful discussions and D. Allan (Plant \& Food Research) for assistance in collecting Zeoliarus oppositus. We would especially like to acknowledge the contribution of Ross Beever, who was the leader of the project to identify new vectors of 'Candidatus Phytoplasma australiense'. Ross sadly passed away in 2010 .

\section{Literature Cited}

1. Andersen, M. T., Beever, R. E., Gilman, A. C., Liefting, L. W., Balmori, E. Beck, D. L., Sutherland, P. W., Bryan, G. T., Gardner, R. C., and Forster, R. L. S. 1998. Detection of Phormium yellow leaf phytoplasma in New Zealand flax (Phormium tenax) using nested PCR. Plant Pathol. 47:188-196.

2. Andersen, M. T., Beever, R. E., Sutherland, P. W., and Forster, R. L. S. 2001. Association of "Candidatus Phytoplasma australiense" with sudden decline of cabbage tree in New Zealand. Plant Dis. 85:462-469.

3. Andersen, M. T., Longmore, J., Liefting, L. W. ,Wood, G. A., Sutherland, P. W., Beck, D. L., and Forster, R. L. S. 1998. Phormium yellow leaf phytoplasma is associated with strawberry lethal yellows disease in New Zealand. Plant Dis. 82:606-609.

4. Andersen, M. T., Newcomb, R. D., Liefting, L. W., and Beever, R. E. 2006. Phylogenetic analysis of "Candidatus Phytoplasma australiense" reveals distinct populations in New Zealand. Phytopathology 96:838-845.

5. Beever, R. E., Forster, R. L. S., Rees-George, J., Robertson, G. I., Wood, G. A., and Winks, C. J. 1996. Sudden decline of cabbage tree (Cordyline australis): search for the cause. N. Z. J. Ecol. 20:53-68.

6. Beever, R. E., Wood, G. A., Andersen, M. T., Pennycook, S. R., Sutherland, R. W., and Forster, R. L. S. 2004. "Candidatus Phytoplasma australiense" in Coprosma robusta in New Zealand. N. Z. Bot. 42:663-675.

7. Bosco, D., and Tedeschi, R. 2013. Insect vector transmission assays. Pages 73-85 in: Phytoplasma: Methods and Protocols, Methods in Molecular Biology, Vol. 938. M. Dickinson and J. Hodgetts, ed. Humana Press, London.

8. Bressan, A., Turata, R., Maixner, M., Spiazzi, S., Boudon-Padieu, E., and Girolami, V. 2007. Vector activity of Hyalesthes obsoletus living on nettles and transmitting a stolbur phytoplasma to grapevines: a case study. Ann. Appl. Biol. 150:331-339.

9. Charles, J. G., Allan, D. J., Andersen, M. T., Langford, G., and Mossop, D. 2002. The search for a vector of strawberry lethal yellows (SLY) in New Zealand. N. Z. Plant Prot. 55:385-389.

10. Cumber, R. A. 1953. Investigations into yellow-leaf disease of Phormium: IV. Experimental induction of yellow-leaf condition on Phormium tenax Forst. by the insect vector Oliarus atkinsoni Myers (Hem. Cixidae). N. Z. J. Sci. Technol. 34A(Suppl. 1):31-40.

11. Cumber, R. A. 1954. Search for alternative vectors of the yellow-leaf disease of Phormium. N. Z. J. Sci. Technol. 36A:32-37.

12. Davis, R. E., Dally, E. L., Gundersen, D. E., Lee, I.-M., and Habili, N. 1997. "Candidatus Phytoplasma australiense," a new phytoplasma taxon associated with Australian grapevine yellows. Int. J. Syst. Bacteriol. 47:262269.

13. Deng, S., and Hiruki, D. 1991. Amplification of 16S rRNA genes from culturable and nonculturable mollicutes. J. Microbiol. Methods 14:53-61.

14. Galetto, L., Bosco, D., Balestrini, R., Genre, A., Fletcher, J., and Marzachi, C. 2011. The major antigenic membrane protein of "Candidatus Phytoplasma asteris" selectively interacts with ATP synthase and actin of leafhopper vectors. PLoS One 6:1-12

15. Gundersen, D. E., and Lee, I. M. 1996. Ultrasensitive detection of phytoplasmas by nested-PCR assays using two universal primer pairs. Phytopathol. Mediterr. 35:144-151.

16. Hogenhout, S. A., Oshima, K., Ammar, E., Kakizawa, S., Kingdom, H. N. and Namba, S. 2008. Phytoplasmas: bacteria that manipulate plants and insects. Mol. Plant Pathol. 9:403-423.

17. IRPCM Phytoplasma/Spiroplasma Working Team-Phytoplasma Taxonomy Group. 2004. "Candidatus Phytoplasma," a taxon for the wall-less, nonhelical prokaryotes that colonize plant phloem and insects. Int. J. Syst. Evol. Microbiol. 54:1243-1255.

18. Kirkpatrick, B. C. 1992. Mycoplasma-like organisms-plant and invertebrate pathogens. Pages 4050-4067 in: The Prokaryotes, vol 4. A. Balows, H. 
G. Truper, M. Dworkin, W. Harder, and K.-H. Schleifer, eds. Springer, New York.

19. Larivière, M.-C. 1999. Cixiidae (Insecta: Hemiptera: Auchenorhyncha). Fauna of New Zealand 40. Manaaki Whenua Press, Lincoln, New Zealand.

20. Larivière, M.-C., and Fletcher, M. J. 2008 A new genus, Zeoliarus, for the endemic New Zealand species Oliarus atkinsoni Myers and O. oppositus (Walker) (Hemiptera: Fulgoromorpha: Cixiidae: Cixiinae: Pentastirini). Zootaxa 1891:66-68.

21. Larivière, M.-C., Fletcher, M. J., and Larochelle, A. 2010. Auchenorrhyncha (Insecta: Hemiptera): Catalogue. Fauna of New Zealand 63. Manaaki Whenua Press, Lincoln, New Zealand.

22. Lee, I. M., Davis, R. E., and Gundersen-Rindal, D. E. 2000. Phytoplasmas: phytopathogenic mollicutes. Annu. Rev. Microbiol. 54:221-255.

23. Lee, I.-M., Hammond, R. W., Davis, R. E., and Gundersen, D. E. 1993. Universal amplification and analysis of pathogen 16S rDNA for classification and identification of mycoplasmalike organisms. Phytopathology 83:834-842.

24. Liefting, L. W., Andersen, M. T., Beever, R. E., Gardner, R. C., and Forster, R. L. S. 1996. Sequence Heterogeneity in the Two 16S rRNA Genes of Phormium yellow leaf Phytoplasma. Appl. Environ. Microbiol. 62:31333139.

25. Liefting, L. W., Beever, R. E., Winks, C. J., Pearson, M. N., and Forster, R. L. S. 1997. Planthopper transmission of Phormium yellow leaf phytoplasma. Australas. Plant Pathol. 26:148-154.

26. Liefting, L. W., Padovan, A. C., Gibb, K. S., Beever, R. E., Andersen, M. T., Newcomb, R. D., Beck, D. L., and Forster, R. L. S. 1998. "Candidatus Phytoplasma australiense" is the phytoplasma associated with Australian grapevine yellows, papaya dieback, and Phormium yellowleaf diseases. Eur. J. Plant Pathol. 104:619-623.
27. Liefting, L. W., Veerakone, S., and Clover, G. R. G. 2011. New hosts of 'Candidatus Phytoplasma australiense' in New Zealand. Australas. Plant Pathol. 40:238-245.

28. Liefting, L. W., Veerakone, S., Ward, L. I., and Clover, G. R. G. 2009. First report of 'Candidatus Phytoplasma australiense' in potato. Plant Dis. 93:969.

29. Newcomb, R. D., and Gleeson, D. M. 1998. Pheromone evolution within the genera Ctenopseustis and Planotortrix (Lepidoptera: Tortricidae) inferred from a phylogeny based on cytochrome oxidase I gene variation. Biochem. Syst. Ecol. 26:473-484.

30. Schneider, B., Gibb, K. S., and Seemüller, E. 1997. Sequence and RFLP analysis of the elongation factor Tu gene used in differentiation and classification of phytoplasmas. Microbiology 143:3381-3389.

31. Schneider, B., Seemüller, E., Smart, C. D., and Kirkpatrick, B. C. 1995 Phylogenetic classification of plant pathogenic mycoplasma-like organisms or phytoplasmas. Pages 369-380 in: Molecular and Diagnostic Procedures in Mycoplasmology, Vol. 1. S. Razin and J. G. Tully, eds. Academic Press, San Diego, CA.

32. Suzuki, S., Oshima, K., Kakizawa, S., Arashida, R., Jung, H.-Y., Yamaji, Y., Nishigawa, H., Ugaki, M., and Namba, S. 2006. Interaction between the membrane protein of a pathogen and insect microfilament complex determines insect-vector specificity. Proc. Natl. Acad. Sci. USA 103:4252-4257.

33. Weintraub, P. G., and Beanland, L. 2006. Insect vectors of phytoplasmas. Annu. Rev. Entomol. 51:91-111.

34. Wood, G. A., Andersen, M. T., Forster, R. L. S., Braithwaite, M., and Hall, H. K. 1999. History of Boysenberry and Youngberry in New Zealand in relation to their problems with Boysenberry decline, the association of a fungal pathogen, and possibly a phytoplasma, with this disease. N. Z. J. Crop Hortic. Sci. 27:281-295. 